Canadian

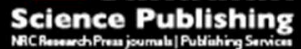

Canadian Journal of Forest Research Revue canadienne de recherche forestière

\title{
Regional effects of alternative climate change and management scenarios on timber production, economic profitability and carbon stocks in Norway spruce forests in Finland
}

\begin{tabular}{|r|l|}
\hline Journal: & Canadian Journal of Forest Research \\
\hline Manuscript ID & cjfr-2015-0218.R1 \\
\hline Manuscript Type: & Article \\
\hline Date Submitted by the Author: & 31 -Oct-2015 \\
\hline Complete List of Authors: & $\begin{array}{l}\text { Zubizarreta-Gerendiain, Ane; University of Eastern Finland, School of } \\
\text { Forest Science; Basque Centre for Climate Change (BC3) } \\
\text { Garcia-Gonzalo, Jordi; Universidade Técnia de Lisboa, Instituto Superior de } \\
\text { Agronomia; Forest Sciences Centre of Catalonia (CEMFOR-CTFC) } \\
\text { Strandman, Harri; University of Eastern Finland, } \\
\text { Jylha, Kirsti; Finnish Meteorological Institute, } \\
\text { Peltola, Heli; University of Eastern Finland, School of Forest Sciences }\end{array}$ \\
\hline Keyword: & $\begin{array}{l}\text { climate warming, forest optimisation, economic profitability, carbon } \\
\text { balance, forest production }\end{array}$ \\
\hline \multicolumn{2}{|c}{} \\
\hline
\end{tabular}


1 Title: Regional effects of alternative climate change and management scenarios

2 on timber production, economic profitability and carbon stocks in Norway

3 spruce forests in Finland

4

5

6

7

8

9

10

11

$12{ }^{1}$ School of Forest Sciences, University of Eastern Finland P.O.Box 111, FI-80101, Joensuu,

13 Finland

14
A. Zubizarreta-Gerendiain ${ }^{1,4 *}$,

J. Garcia-Gonzalo ${ }^{2}$,

H. Strandman ${ }^{1}$,

H. Peltola ${ }^{1}$
K. Jylhä ${ }^{3}$ (ane.zubizarreta@uef.fi)

(jordigarcia@isa.ulisboa.pt)

(Harri.strandman@uef.fi)

(kirsti.jylha@fmi.fi)

(Heli.peltola@uef.fi)
${ }^{2}$ Centro de Estudos Florestais, Instituto Superior de Agronomia, Universidade de Lisboa, Portugal

${ }^{3}$ Finnish Meteorological Institute, P.O.Box 503, FO-00101 Helsinki, Finland

${ }^{4}$ Basque Centre for Climate Change (BC3), 48008, Bilbao, Spain

* Corresponding author:

Ane Zubizarreta-Gerendiain

ane.zubizarreta@uef.fi

Phone number: +358449667503

Fax: +358294457316 


\section{ABSTRACT}

26 We studied regional effects of alternative climate change and management scenarios on 27 timber production, its economic profitability (NPV with $2 \%$ interest rate) and carbon stocks over a 90 years simulation period in Norway spruce forests located in southern, central and northern Finland. We also compared the results of optimised management plans (maximizing incomes) and fixed management scenarios. Business-as-usual (BAU) management recommendations were used as basis for alternative management scenarios. The forest ecosystem model SIMA together with a forest optimisation tool was employed. To consider the uncertainties related to climate change, we applied two climate change scenarios (SRES B1 and A2) in addition to the current climate.

Results showed that timber production, NPV and carbon stocks of forests would reduce in southern Finland, opposite to northern Finland, and especially under the strong climate change scenario (SRES A2) compared to the current climate. In central Finland, climate change would have little effect. The use of optimised management plans also resulted in higher timber yield, NPV and carbon stock of forests compared to the use of a single management scenario, regardless of forest region and climate scenario applied. In the future, we may need to modify the current BAU management recommendations to properly adapt to the changing climatic conditions.

Keywords: climate warming; carbon balance; forest production; forest optimisation; economic profitability. 


\section{INTRODUCTION}

48 Nowadays, short growing season, low summer temperatures and lack of available nitrogen 49 limit the productivity of boreal forests. However, the global climate is expected to warm substantially in the future due to the rapid increase of greenhouse gases and especially carbon dioxide in the atmosphere (IPCC 2013). Under the gradually changing climate, carbon sequestration and productivity of managed boreal forests are, in general, expected to increase in Finland due to longer growing seasons and increase of temperature, atmospheric $\mathrm{CO}_{2}$ concentration and precipitation (Kellomäki et al. 2008; Zubizarreta-Gerendiain et al. 2015a). Under the warming climate, the increased decomposition rate of soil organic matter may also increase the nitrogen availability for forest growth (Jarvis et al. 2005). On the other hand, productivity of Norway spruce (Picea abies) with shallow rooting may suffer from drought on soils with relatively low water holding capacity, especially in southern Finland (Ge et al. 2011, 2013a, 2013b; Kellomäki et al. 2008).

In addition to climatic and site conditions, forest structure as controlled by forest management also affects forest productivity (growth and timber yield) and carbon sequestration and stocks of forests (Garcia-Gonzalo et al. 2007a; Pyörälä et al. 2014; Zubizarreta-Gerendiain et al. 2015b). Forest productivity and carbon stocks could be increased for example, by using less intensive thinnings and by maintaining growing stock volumes higher and applying longer rotation lengths (e.g. Liski et al. 2001; Pukkala et al. 2011). However, this may decrease the economic profitability of forestry due to the delayed harvesting, especially if a high interest rate is used in calculation of the net present value. Under the changing climate, currently applied business-as-usual management practices (e.g. forest regeneration, thinning and rotation length) may need to be modified to fully utilise the increased productivity and decrease the negative effects of climate change (Garcia-Gonzalo et al. 2008; Pukkala and 
Kellomäki 2012; Zubizarreta-Gerendiain et al. 2015a; Torssonen et al. 2015). Forest landscapes should also consist of a mosaic of stands with different development stages to maintain sustainable timber production and carbon sequestration and stock of forests over time (Garcia-Gonzalo et al. 2007a). This is because newly regenerated sites and over mature forests (latter ones having high carbon stocks) may act even as sources of carbon instead of sinks opposite to young and medium age stands (Jarvis et al. 2005).

Forest ecosystem models offer useful means to study the sensitivity of forest growth, timber production, economic profitability of forestry and carbon sequestration (and stocks) of forests to changes in environmental conditions (e.g. climate and site fertility) and forest management (Kellomäki et al. 2008; Matala et al. 2003, 2005, 2006). The outputs of forest ecosystem model simulations can also be used as inputs for forest optimisation tools to solve forest planning problems. The integrated use of forest ecosystem model simulations and optimisation techniques allow identifying adaptive measures, which could increase forest production and/or forest carbon stocks in a sustainable and cost-efficient way (e.g. GarciaGonzalo et al. 2014). So far, only few attempts exist to optimise forest management under changing climatic conditions (e.g. Nuutinen et al. 2006; Garcia-Gonzalo et al. 2008, 2014; Pukkala and Kellomäki 2012; Zubizarreta-Gerendiain et al. 2015a,b). Furthermore, these studies have typically considered only one climate change scenario despite of uncertainties of the future climate projections.

In this work, we employed the forest ecosystem model SIMA (Kellomäki et al. 1992a, 1992b, 2008) together with a forest optimisation tool to study the regional effects of different climate change and management scenarios on timber production, its economic profitability (NPV with $2 \%$ interest rate) and carbon stocks over a 90 years simulation period in Norway spruce 
97 forests located in southern, central and northern Finland. We also compared these results to 98 those of optimised management plans, in which different management alternatives could be 99 applied simultaneously in a forest region. Business-as-usual (BAU) Finnish forest 100 management recommendations were used as a basis for alternative management scenarios in 101 forest ecosystem model simulations. Their outputs were further on used as inputs for a forest optimisation tool. In order to consider the uncertainties related to the projected climate change, we applied two different climate change scenarios (SRES B1 and SRES A2) in addition to the current climate. The main hypothesis of our work was that different management and climate change scenarios could even have opposite effects on timber production, its economic profitability and carbon stocks of forests, depending on regions of Finland. Furthermore, we expected that the results of optimised management plans differ from those of using the same fixed management scenarios.

\section{MATERIAL AND METHODS}

\section{Outlines for the simulations and optimisation}

112 Outlines for SIMA model simulations and optimisation. The SIMA gap-type forest ecosystem model (Kellomäki et al. 1992a, 1992b, 2008) was used to predict forest productivity and carbon stocks in Norway spruce forests from southern to northern Finland under alternative forest management and climate change scenarios over a 90-year simulation period. The outputs of simulations (i.e. timber production, economic revenues and carbon stocks of

117 forests) were used as inputs for a linear programming model to find out the maximum 118 sustainable timber yield for each simulation cases.

In the SIMA model, the regeneration, growth and mortality of tree stands are affected by 
moisture and atmospheric $\mathrm{CO}_{2}$ (Kellomäki et al. 2008). In addition, they are affected by forest management, which affects the availability of resources for growth. Management control includes natural and artificial regeneration with desired spacing and selected tree species, control of stand density by tending of seedling stand and thinning, nitrogen fertilisation, and choice of rotation length based on tree age or alternatively basal area weighted mean diameter of trees at breast height ( $1.3 \mathrm{~m}$ above stem base). The simulations are carried out on an area of $100 \mathrm{~m}^{2}$ with a one-year time step. The simulations are based on the Monte Carlo technique to take into account stochastic events (i.e. such as birth and death of trees) and therefore, each simulation is repeated many times (20 times in this work) and only their mean tendency of output variables are used in data analyses, as was done before in the work of Torssonen et al. (2015), for example.

The SIMA model has been parameterised for Norway spruce, Scots pine (Pinus sylvestris), silver birch (Betula pendula) and downy birch (Betula pubescens) growing throughout Finland (latitudes $\mathrm{N} 60^{\circ}$ and $\mathrm{N} 70^{\circ}$ and longitudes E $20^{\circ}$ and $\mathrm{E} 32^{\circ}$ ). Previous predictions of the SIMA model have shown good agreement with measured volume growth on permanent sample plots of the National Forest Inventory (NFI) throughout Finland, parallel simulations made by empirical growth model Motti (see Hynynen et al. 2002; Matala et al. 2005, 2006), and measured growth response of trees to nitrogen deposition (see e.g. Mäkipää et al. 1998; Matala et al. 2003; Routa et al. 2011a, 2011b).

Description of model forest areas. In this work, model stand data was used to generate three artificial pure Norway spruce forests (areas of 1000 ha each) located in southern $\left(60^{\circ} \mathrm{N}\right.$, Helsinki), central $\left(62^{\circ} \mathrm{N}\right.$, Kuopio) and northern $\left(66^{\circ} \mathrm{N}\right.$, Rovaniemi) Finland on medium fertile (MT) site types. The model stand data for analysis consisted of 9 model stands, representing 
147 an age class range from 5 to 85 years (ten year interval). The amount of initial soil organic 148 matter and initial tree stand characteristics for the 9 stands representing different age classes 149 were created using current climate and business-as-usual Finnish forest management (Äijälä 150 et al. 2014). Forest ecosystem carbon stock included carbon in soil and trees (stem, branches 151 and foliage and coarse and fine roots). In the simulations, an annual nitrogen deposition of 10 $152 \mathrm{~kg} \mathrm{ha}^{-1}$ was used. In order to generate forest areas with an even age-class distribution (four 153 age classes), different age classes were further grouped into age class groups, each 154 representing $25 \%$ of the total area of 1000 ha (Table 1 ).

Table 1

157

Forest management scenarios. The development of each Norway spruce stand was simulated for the period 2010-2100. Stands with a dominant height $\geq 12 \mathrm{~m}$ were thinned from below and a basal area was reduced to the given target level. In order to generate a set of management alternatives, the basic thinning regime (business-as-usual management, see Äijälä et al. 2014) was varied by changing the upper thinning threshold $(-10,+10$ and $+20 \%)$ and the percentage of basal area removal in the first thinning (50 and $65 \%)$ and in the following thinnings $(20,30$ and $40 \%$ ). In addition, stands could have the final cut at ages of $60,70,80$ or 90 years (see table 2). All these different possibilities provided a total of 96 management alternatives for each climatic condition and forest region. After clear-cutting, the regeneration area was planted with an initial stand density of 2500 Norway spruce seedlings $\mathrm{ha}^{-1}$ and simulation continued until the end of the 90 years planning period. Trees cut in thinning and final cut were considered as saw logs, pulpwood or logging residuals depending on their dimensions. The minimum tree diameter was $15 \mathrm{~cm}$ for sawlogs and $6 \mathrm{~cm}$ for pulpwood. Smaller stems were treated as logging residuals (with no monetary value). 
173 The outputs of all simulations were used as inputs for the optimisation. The optimisation finds

174 the best management plan fulfilling the optimisation targets, by employing a combination of 175 different management alternatives over the region (i.e. the selection of one management 176 alternative for each stand to be applied over the whole planning horizon). Furthermore, a sub177 set of six management alternatives was selected (Table 2) to study more in details how the 178 results of optimised management plans differ compared to those applying fixed management 179 scenarios over the whole forest region and 90 years simulation period.

Table 2

182

Climate scenarios. In addition to the current climate, two different climate change scenarios

were used for the simulations. The current climate represented the monthly mean values of temperature and precipitation and the annual mean $\mathrm{CO}_{2}$ of the years 1961-2000. The current climate data were interpolated onto a $10 \mathrm{~km}$ x $10 \mathrm{~km}$ grid based on mean monthly values (Venäläinen et al. 2005). Climate change scenarios used were the IPCC SRES A2 (strong climate change) and B1 (mild climate change) emission scenarios as calculated based on monthly mean output data from 19 global climate models of the CMIP3 multi-model dataset (Meehl et al. 2007). Their predicted changes in temperature and precipitation were interpolated onto a $50 \mathrm{~km}$ x $50 \mathrm{~km}$ grid (Jylhä et al. 2009). According to these scenarios, winter and summer temperatures (T) will increase in Finland by $4-7^{\circ} \mathrm{C}$ and $2-3^{\circ} \mathrm{C}$, precipitation $(\mathrm{P})$ by about $14-30 \%$ in winter and by about $8-10 \%$ in summer and the atmospheric $\mathrm{CO}_{2}$ to about 540 (B1) and $840 \mathrm{ppm}(\mathrm{A} 2)$ by 2100 from the current value of 360 ppm, respectively. The closest grid point to each forest area was used in the simulations under the current climate and changing climate scenarios. The elevation of $T$, atmospheric $\mathrm{CO}_{2}$ and 
201

202

203

204

205

206

207

208

209

210

211

212

213

214

215

216

217

$219 \quad \mathrm{Max} \mathrm{FV}=\sum_{i=1}^{N} \sum_{j=1}^{M_{i}} f v_{i j} x_{i j} A_{i}$

220

$221 \quad \sum_{j=1}^{M_{i}} x_{i j}=1, i=1, \ldots, N$

Subject to:

RCP4.5 of the new CMIP5 database (Taylor et al., 2012), whereas the SRES A2 shows 1.31.5 smaller temperature increase in summer from southern to northern Finland compared to the RCP8.5 (Taylor et al., 2012).

Costs of forest operations and prices of different assortments used in NPV calculation. The calculated forest value included the net present value (NPV, with $2 \%$ interest rate) of forest revenues over the planning horizon (90 years). The prices used for different assortments were based on the average stumpage prices $\left(41 € \mathrm{~m}^{-3}\right.$ for saw $\operatorname{logs} 15 € \mathrm{~m}^{-3}$ for pulp wood, according to the Finnish Statistical Yearbook of Forestry (Metla, 2010)).

\section{Mathematical formulations for the optimisation}

Timber yield, revenues and carbon stocks for all management alternatives applied to each stand and climatic conditions were used to develop the mathematical formulation of the planning model (i.e. the coefficients for all the equations below). For the optimised plan, the objective was to maximise net incomes (i.e maximisation of net present value using a $2 \%$ discounting rate) ensuring a non-declining timber yield over the years. Non-declining yield constraints were applied to avoid over-cutting the forest. The study considered a 90-year planning horizon and three alternative climates. In order to assess the impacts of climate change on net revenues, timber production and carbon stocks, the model included several accounting variables. A Model I type formulation described by Johnson \& Scheurman (1977) was used. The test problem may be described as: 
$222 \quad \sum_{i=1}^{N} \sum_{j=1}^{M_{i}} w_{i j t} x_{i j} A_{i}=W_{t}, t=1, \ldots, T$

$223 \quad \sum_{i=1}^{N} \sum_{j=1}^{M_{i}} \operatorname{carb}_{i j t} x_{i j} A_{i}=C A R B_{t}, t=1, \ldots, T$

$224 \quad \sum_{i=1}^{N} \sum_{j=1}^{M_{i}} n p v_{i j t} x_{i j} A_{i}=N P V_{t}, t=1, \ldots, T$

$225 \quad \sum_{i=1}^{N} \sum_{j=1}^{M_{i}} n r_{i j t} x_{i j} A_{i}=N R_{t}, t=1, \ldots, T$

226

227

$W_{t+1} \leq(1+$ alpha $) \cdot W_{t}, t=1, \ldots, T-1$

228

$W_{t+1} \geq \cdot W_{t}, t=1, \ldots, T-1$

229

$0 \leq x_{i j} \leq 1, \forall i, j$

230

231

232

233

234

235

236

237

238

239

240

241

242 where, $F V$ is total net present forest value (includes value of the ending inventory), $N$ is number of stands, $A_{i}$ is area of the stand $I, x_{i j}$ is the decision variable and defines the proportion of the stand $\mathrm{i}$ that is assigned to management alternative $\mathrm{j}$ (the values range between 0 and 1), $T$ is number of periods during the planning horizon (90), $M_{i}$ is number of prescriptions for stand $\mathrm{I}, f v_{i j}$ is forest value per ha associated with prescription $j$ and stand $I$ (forest value includes the value of the ending inventory), $\mathrm{w}_{\mathrm{ijt}}$ is harvested timber flow per ha in period t that results from assigning prescription $j$ to stand $\mathrm{I}, \operatorname{carb}_{i j t}$ is average carbon stock per ha in stand $i$ in period $t$ if prescription $j$ is selected, $n r_{i j t}$ is net revenue per ha in period $t$ associated to prescription $j$ in stand $I, n p v_{i j t}$ is discounted net revenue per ha in period $t$ associated to prescription $j$ in stand $I$, and alpha is deviation allowed from target level (e.g. $15 \%$ variation). 
243 Equation (1) defines the objective of maximising FV. Equation (2) ensures that one and only

244 one prescription is assigned to each stand. Equations 3, 4, 5 and 6 account for timber yield,

245 average carbon stock, net revenue and discounted revenue in each planning period. Equations

2467 and 8 force timber yield levels to meet the flow targets in each period. They reflect concerns

247 with the sustainability of timber supply where timber harvested in successive periods can

248 increase up to $15 \%$ but cannot decrease. Equation 9 ensures that the decision variables take a

$249 \quad$ value between 0 and 1.

250

251

RESULTS

252 Carbon stock of forests

253 The total carbon stock of forest (in soil and trees) was clearly affected by climatic conditions

254 (Fig 1). Compared to the current climate, total carbon stock of forest in southern Finland was

255 up to $15-23 \%$ lower under the B1 and A2 scenarios than under the current climate, depending

256 on the applied management scenario (Fig1, Table3). In central Finland, total carbon stock

257 was slightly lower under both climate change scenarios (up to $10 \%$ less) compared to the

258 current climate. This was opposite to northern Finland, where carbon stock of forests

259 increased under both climate change scenarios (up to $8 \%$ higher).

260

261

Table 3

262

263

When heavy thinnings were applied, the carbon stock of the forest was lower than with baseline and light thinning, regardless of the forest region, rotation length and climate applied

(Fig 1). Management scenarios with long rotation length (90 years) also resulted in higher carbon stocks compared to those with shorter rotation length (70 years). Optimised 
267

268

269

270

271

272

273

274

275

276

277

278

279

280

281

282

283

284

285

286

287

288

289

290

291

management plans, in general, resulted in higher carbon stocks of forests than the base-70 management alternative.

The carbon stock in soil was lower under both climate change scenarios than under the current climate regardless of region and management applied. Similarly, the carbon stock in trees was lower in southern Finland under both climate change scenarios than under the current climate. In central Finland, the carbon stock in trees was similar under the current climate and B1 scenario, while it was slightly lower under the A2 scenario. In northern Finland, the carbon stock in trees was higher under both climate change scenarios than under the current climate, regardless of management scenario.

\section{Fig 1.}

\section{Timber yield and NPV}

In southern Finland, under both climate change scenarios the total timber yield over the 90 years simulation period was lower compared to the current climate, regardless of management scenario applied (Fig 2). Under the A2 and B1 climate change scenarios, harvested timber yield was $26-43 \%$ and $13-19 \%$ lower than under the current climate, depending on the management scenario used (Table 3). Also for the optimised management scenario, it decreased by 36 and $11 \%$ under the $\mathrm{A} 2$ and $\mathrm{B} 1$ scenarios, compared to the current climate. Shorter rotation lengths also showed smaller decrease than longer ones, especially under the A2 scenario. In central Finland, the total timber yield reduced slightly under the A2 scenario (decrease 3 to 5\%) for different management scenarios, while under the B1 scenario was similar to that under the current climate (table 3). For the optimised management plan, timber yield reduced $4 \%$ under the A2 scenario compared to the current climate, while under the B1 
292 scenario no change was observed. In northern Finland, timber yield increased for all 293 management scenarios $21-26 \%$ under the A2 scenario and 19-23\% under the B1 scenario 294 compared to the current climate. (Fig. 2) This increase was higher with shorter rotation 295 lengths. In the optimised management, timber yield increased 22 and $20 \%$ under the A2 and B1 scenarios compared to the current climate (Table 3).

Fig 2.

Under the current climate, the use of business-as-usual management (70-base) provided the highest timber yield over the 90 years simulation period in southern and central Finland, if not considering the optimised management (Fig 2). Furthermore, under both climate change scenarios, the 70-base management was among those providing the highest timber yield, regardless of forest region. In the optimised management plan (i.e. a combined use of different management scenarios over the region), the harvested timber yield was, in general, considerably higher than with any fixed management scenario, regardless of climate scenario and forest region considered, except under the A2 scenario in southern Finland (Fig. 2, table 3). In southern Finland, when applying the optimised management plan instead of a fixed one, such as business as usual (70- base), the harvested timber yield over the 90 years simulation period increased 7 and $13 \%$ under the current climate and the climate change scenario B1, management scenario regardless of climate applied.

315 
317

318

319

320

321

322

323

324

325

326

327

328

329

330

331

332

333

334

335

336

337

\section{Table 4.}

In southern Finland, shorter rotation lengths clearly provided higher timber yield than longer rotation lengths regardless of climatic conditions, and especially under the A2 scenario (Fig 2). In central Finland, shorter rotation lengths resulted in slightly higher timber yield. In northern Finland the harvested timber yield was not clearly affected by rotation length, regardless of climate applied. But if the standing volume of growing stock at year 90 was also considered, the total timber volume (standing and harvested) was higher for longer rotations, in all other simulation cases except in southern Finland under the A2 climate change scenario (Table 5). The optimised management plan also resulted in considerably higher total timber volumes (standing and harvested volume) regardless of the applied climate and region. In the optimised plan, long rotation lengths were in general more common (80-90 years) and shortest ones (60 years) were not used. Considering the intensity of first thinning, $50 \%$ of the removal was more usual compared to the $65 \%$, regardless of the region and climate applied.

\section{Table 5.}

Net present value (NPV) over the planning horizon (90 years) was in southern Finland lower under both climate change scenarios compared to the current climate, regardless of management scenario applied (Fig 3). For instance, under the 70-base management, NPV was 12 and 20\% lower under the B1 and A2 scenarios, compared to the current climate (Table 3). For the optimised management, it was 7 and 30\% lower under the B1 and A2 scenarios, respectively. In central Finland, climate change did not largely affect NPV (difference up to $2.5 \%$ compared to the current climate). In northern Finland, NPV was depending on management scenario $13-20 \%$ higher under the B1 and A2 scenarios compared to the current 
342 climate. For the optimised management plan, the NPV was $18-19 \%$ higher under the B1 and

343 A2 scenarios, compared to the current climate.

345 Among different fixed management alternatives in southern Finland the highest NPV values 346 were obtained with 70-base and 70-heavy management scenarios, regardless of the climate 347 scenario applied (Fig 3). The use of light thinnings and/or longer rotations resulted in lower 348 NPV. In central Finland, the general trend was the same as in southern Finland. In northern 349 Finland, management scenarios applying heavy thinnings and long rotation lengths (90350 heavy) provided similar NPV values than 70-base and 70-heavy management scenarios. In 351 general, the NPV for the optimised plan was considerably higher than for other fixed 352 management scenarios, regardless of forest region and climate applied. However, in southern 353 Finland under the A2 scenario, several fixed management alternatives such as 70-heavy management resulted in a higher NPV than the optimised scenario (Fig.3).

Fig 3.

357

\section{DISCUSSION AND CONCLUSIONS}

359

360

361

362

363
In this work, we studied regional effects of different climate change and management scenarios on timber production, its economic profitability (NPV with $2 \%$ interest rate) and carbon stocks over a 90 years simulation period in Norway spruce forests located in southern, central and northern Finland. We also compared these results to those of optimised management plans, in which different management alternatives could simultaneously be applied in a forest region. Business-as-usual Finnish forest management recommendations were used as a basis for alternative management scenarios in forest ecosystem model SIMA simulations. In order to consider the uncertainties related to the projected climate change, we 
367

368

369

370

371

372

373

374

375

applied two different climate change scenarios (SRES B1 and SRES A2) in addition to the current climate. The outputs of the model were further on used as inputs for a forest optimisation tool. Altogether, we used 96 different management cases for each forest region and climatic condition as inputs for the optimisation tool to maximise the NPV, ensuring simultaneously a non-declining timber yield over the simulation period. However, based on preliminary analyses (not shown in details in this work), we selected six representative management alternatives to demonstrate the main patterns of findings (see Table 2). This was done because it would have been too complex to show all the results for each 96 management cases separately.

Our results demonstrated that climate change will, in different ways, affect timber yield, its NPV and carbon stocks of Norway spruce forests in different forest regions in Finland. It also affected total carbon stock of forests via changes in soil carbon and tree carbon, respectively. Regardless of the management scenario, total carbon stock of forest decreased in southern Finland under the changing climate (especially under A2) due to decrease in tree growth and increase in decomposition of the soil organic matter. On the contrary, in northern Finland climate change increased tree growth and thus carbon stock in trees. However, total carbon stock of forest varied also largely depending on the management scenario used. In our study as well as in previous ones (e.g. Garcia-Gonzalo et al. 2007b), lower thinning intensity and longer rotation lengths resulted in, on average, higher carbon stocks of forests.

Timber production decreased considerably in southern Finland under both changing climate scenarios, and especially under the stronger A2 scenario. These results can be explained by the fact that the growth of Norway spruce is expected to suffer drought in southern Finland especially on sites with low water holding capacity (Kellomäki et al. 2008; Ge et al. 2013a). Thus, if strong climate change occurs, tree species more resistant to drought, such as Scots pine, should be preferred in cultivation on such soils in Finland (Kellomäki et al. 2008). 
392

393

394

395

396

397

398

399

400

401

402

403

404

405

406

407

408

409

410

411

412

413

414

415

416

According to our results, in central Finland timber yield was not largely affected by the changing climate. In northern Finland timber yield increased clearly, which could be explained by the fact that low summer temperatures are currently limiting forest growth there (Briceño-Elizondo et al. 2006; Ge et al. 2013b). Our findings are in line, for example, with the study of Coomes et al. (2014), who suggested that climate change effects on timber production vary also depending on the forest region and its environmental conditions.

Even if our results showed that the studied management alternatives could not fully compensate the loss of timber production under the strong climate change (the A2 scenario), some of them showed a lower production decrease. In general, heavier thinnings and shorter rotation lengths should be preferred especially in southern Finland to reduce competition among trees for growth resources and to moderate the mortality of trees under the strong climate change. Fortunately, the most drastic effects of climate change are expected later in this century and we have, in this sense, some time to gradually adapt our forest management to these conditions. Nonetheless, the expected impacts also differ depending on the projected climate change as we demonstrated in this work.

Usually in unthinned or slightly thinned forests the total carbon stock is higher than in more heavily managed ones (with earlier and/or more intensive thinnings), opposite to the NPV (Garcia-Gonzalo et al. 2007b). In our study, NPV showed in general a decreasing tendency from heavy to light thinning, and from shorter to longer rotation lengths (Fig 3). This was opposite to the total carbon stock of forest (Fig 2). So, there is a trade-off between the NPV and carbon stock of forests. Nonetheless, our optimisation results showed that it is also possible to increase simultaneously the NPV and average carbon stock of forest over 90 years simulation period compared to the use of one fixed management scenario. However, to study 
417 more in details these trade-offs among multiple criteria, multi-objective optimisation

418 techniques should be applied in future studies.

Our results showed, that the business as usual management used nowadays in Finland (Äijälä

et al. 2014) is competitive in terms of timber yields under the current climate, unlike under the strong climate change (A2 scenario). However, the use of the same fixed management scenario over a whole forest region may result in heavy fluctuations of timber yields and unprofitable cuttings over time. Therefore, optimisation can be used to find the best combination of management alternatives over the forest region, when considering certain management objectives (e.g. NPV, carbon stock) and constraints (e.g. non-declining timber yield, revenues). In the present study, when management was optimised for the whole forest region, it gave higher NPV for all study cases and climatic conditions, expect in southern Finland under the A2 scenario with substantially lower timber yield. Furthermore, in the optimisation we tried to satisfy the non-declining timber yields over time, which maintained the volume of growing stock higher over the planning period and resulted in lower amount of harvested timber compared to the use of fixed single management scenarios.

To conclude, in general our optimised management plan resulted in a more profitable forest management with a sustainable harvest and incomes during the planning horizon, which is more often used. Considering the intensity of the first thinning, 50\% of the volume removal was more recurrent compared to $65 \%$, regardless of the region and climate applied. Based on our findings, the current Finnish management practices may need to be regionally modified in the future to properly adapt to the changing climatic conditions. However, possible increase 
442 of abiotic risks to forests, for example, by wind, may also influence these needs, which should 443 be studied more in details in the future.

444

445

446

447

448

449

450

451

452

453

454

455

456

457

458

459

460

461

462

463

464

465

\section{ACKNOWLEDGMENTS}

This work was partly funded by the UEF foundation (project 930341 at the University of Eastern Finland), and the project PTDC/AGR-FOR/4526/2012 Models and Decision Support Systems for Addressing Risk and Uncertainty in Forest Planning (SADRI) financed by the Portuguese national funding agency for science, research and technology (FCT). Furthermore, it has also been supported by the ongoing project on Adaptation of forest management to climate change: uncertainties, impacts and risks to forests and forestry in Finland (ADAPT, project 14907, funded by Academy of Finland, consortium project between UEF and Finnish Meteorological Institute, 2012-2016), coordinated by Prof. Heli Peltola at UEF. The Finnish Meteorological Institute, and especially Kimmo Ruosteenoja, is acknowledged for providing the current climate and climate change scenarios for this work.

\section{REFERENCES}

Äijälä, O., Koistinen, A,, Sved, J., Vanhatalo, K. and Väisänen, P. (eds) 2014. Hyvän metsänhoidon suositukset - Metsänhoito (Recommendations for good forest management - forest management), Forestry Development Centre Tapio. 264 p. (In Finnish).

Briceño-Elizondo, E., Garcia-Gonzalo, J., Peltola, H., Matala, J. and Kellomäki, S. 2006. Sensitivity of growth of Scots pine, Norway spruce and silver birch to climate change 

and forest management in boreal conditions. Forest Ecology and Management 232, 1-3, 152-167.

Coomes, D.A., Flores, O., Holdaway, R., Jucker, T., Lines, E.R. and Vanderwel, M.C. 2014. Wood production response to climate change will depend critically on forest composition and structure. Global Change Biology 20, 3632-3645

Garcia-Gonzalo, J., Borges, J.G., Palma, J.H.N. and Zubizarreta-Gerendiain, A. 2014. A decision support system for management planning of Eucalyptus plantations facing climate change. Annals of Forest Science 71,187-199

Garcia-Gonzalo, J., Jäger, D., Lexer, M.J., Peltola, H., Briceño-Elizondo, E. and Kellomäki, S. 2008. Does climate change affect optimal planning solutions for multi-objective forest management? Allgemeine Forst und Jagdzeitung (AFJZ)-German Journal of Forest Research 179 (5-6), 78-95

Garcia-Gonzalo, J., Peltola, H., Zubizarreta Gerendiain, A. and Kellomäki, S. 2007a. Impacts of forest landscape structure and management on timber production and carbon stocks in the boreal forest ecosystem under changing climate. Forest Ecology and Management 241:243-257.

Garcia-Gonzalo, J., Peltola, H., Briceño-Elizondo, E. and Kellomäki, S. 2007b. Effects of climate change and management on timber yield in boreal forests, with economic implications: A case study. Ecological Modelling 209(2-4), 220-234.

Ge, Z.M., Kellomäki, S., Peltola, H., Zhou, X., Väisänen, H. and Strandman, H. $2013 a$. Impacts of climate change on primary production and carbon sequestration of boreal Norway spruce forests: Finland as a model. Climatic Change 118(2), 259-273.

Ge, Z.M, Kellomäki, S., Peltola, H., Zhou, X., Väisänen, H. 2013b. Adaptive management to climate change for Norway spruce forests along a regional gradient in Finland. Climatic Change1 18:275-289 
Ge, Z.M., Kellomäki, S., Peltola, H., Zhou, X., Wang, K-Y. and Väisänen, H. 2011. Effects of varying thinning regimes on carbon uptake, total stem wood growth, and timber production in Norway spruce (Picea abies) stands in southern Finland under the changing climate. Annals of Forest Science 68:371-383

Hynynen, J., Ojansuu, R., Hökkä, H., Salminen, H., Siipilehto, J. and Haapala, P. 2002 Models for predicting stand development in MELA System. The Finnish Forest Research Institute. Research Papers 835. 116 p.

IPCC. 2013 Summary for Policymakers. In: Climate Change 2013: The Physical Science Basis. Contribution of Working Group I to the Fifth Assessment Report of the Intergovernmental Panel on Climate Change. Stocker T.F., D. Qin, G.-K. Plattner, M. Tignor, S. K. Allen, J. Boschung, A. Nauels, Y. Xia, V. Bex and P.M. Midgley (eds.). Cambridge University Press, Cambridge, United Kingdom and New York, NY, USA.

Jarvis, P.G., Ibrom, A. and Linder, S. 2005. Carbon forestry-managing forests to conserve carbon. In: Griffiths, H., Jarvis, P.G. (Eds.), The Carbon Balance of Forest Biomes. Taylor \& Francis Group, UK, ISBN: 1-8599-6214-9 pp. 331-349.

Johnson, K.N. and Scheurman, H.L. 1977. Techniques for prescribing optimal timber harvest and investment under different objectives - discussion and synthesis Forest Science Monograph Number 18, $31 \mathrm{p}$.

Jylhä, K., Ruosteenoja, K., Räisänen, J., Venäläinen, A., Tuomenvirta, H., Ruokolainen, L., Saku, S. and Seitola, S. 2009 Arvioita Suomen muuttuvasta ilmastosta sopeutumistutkimuksia varten. ACCLIM-hankkeen raportti 2009 (The changing climate in Finland: estimates for adaptation studies. ACCLIM project report 2009.) Finnish Meteorological Institute, Reports 2009:4 102 pages. In Finnish, abstract, extended abstract and captions for figures and tables also in English) 
515 Kellomäki, S., Peltola, H., Nuutinen, T., Korhonen, K.T. and Strandman, H. 2008. Sensitivity

516 of managed boreal forests in Finland to climate change, with implications for adaptive

517 management. Philosophical Transactions B: Biological Sciences 363, 2341-235.

518 Kellomäki, S., Väisänen, H., Hänninen, H., Kolström, T., Lauhanen, R., Mattila, U. and

519 Pajari, B. 1992a. A simulation model for the succession of the boreal forest ecosystem.

$520 \quad$ Silva Fennica 26, 1-18.

521 Kellomäki, S., Väisänen, H., Hänninen, H., Kolström, T., Lauhanen, R., Mattila, U. and Pajari

522 B. 1992b. SIMA: a model for forest succession based on the carbon and nitrogen cycles

523 with application to silvicultural management of the forest ecosystem. Silva Carelica 22,

$524 \quad 85$.

525 Liski, J., Pussinen, A., Pingoud, K., Mäkipää, R. and Karjalainen, T. 2001. Which rotation

526 length is favourable to carbon sequestration? Canadian Journal of Forest Research 31, $527 \quad 2004-2013$

528 Matala, J., Ojansuu, R., Peltola, H., Raitio, H. and Kellomäki, S. 2006. Modelling the 529 response of tree growth to temperature and $\mathrm{CO} 2$ elevation as related to the fertility and current temperature sum of a site. Ecological Modelling 199:39-52.

Matala, J., Ojansuu, R., Peltola, H., Sievänen, R. and Kellomäki, S. 2005. Introducing effects of temperature and $\mathrm{CO} 2$ elevation on tree growth into a statistical growth and yield model. Ecological Modelling 181:173-190.

Matala, J., Hynynen, J., Miina, J., Ojansuu, R. Peltola, H., Sievänen, R., Väisänen, H. and Kellomäki, S. 2003. Comparison of a physiological model and a statistical model for prediction of growth and yield in boreal forests. Ecological Modelling 161, 95-116.

Meehl, G.A., Covey, C., Delworth, T., Latif, M., McAvaney, B., Mitchell, J. F. B., Stouffer, 538 R .J. and Taylor K.E. 2007. The WCRP CMIP3 Multimodel Dataset: A New Era in Climate Change Research. Bull. Amer. Meteor. Soc. 88, 1383-1394. 
METLA. 2010. Metsätilastollinen Vuosikirja 2010 (Finnish Statistical Yearbook of Forestry, 2010. Sastamala: Vammalan Kirjapaino Oy.

Mäkipää, R., Karjalainen, T., Pussinen, A. and Kukkola, M. 1998. Effects of nitrogen fertilization on carbon accumulation in boreal forests: model computations compared with the results of long-term fertilization experiments. Chemosphere 36, 1155-1160.

Nuutinen, T., Matala, J., Hirvelä, H., Härkönen, K., Peltola, H., Väisänen, H. and Kellomäki, S. 2006. Regionally optimized forest management under changing climate. Climatic Change 79, 315-333

Pukkala, T., and Kellomäki, S. 2012. Anticipatory vs. adaptive optimization of stand management when tree growth and timber prices are stochastic. Forestry 85(4), 463472.

Pukkala, T., Lähde, E., Laiho, O., Salo, K. and Hotanen, J.-P. 2011. A multifunctional comparison of even-aged and uneven-aged forest management in a boreal region. Canadian Journal of Forest Research 41, 851-862.

Pyörälä, P., Peltola, H., Strandman, H., Kilpeläinen, A., Asikainen, A., Jylhä, K. and Kellomäki, S. 2014. Effects of management on economic profitability of forest biomass production and carbon neutrality of bioenergy use in Norway spruce stands under the changing climate. Bioenergy Research 7(1):279-294

Routa, J., Kellomäki, S., Kilpeläinen, A., Peltola, H., Strandman, H. $2011 a$. Effects of forest management on the carbon dioxide emissions of wood energy in integrated production of timber and energy biomass. Global Change Biology Bioenergy 3(6), 483-497.

Routa, J., Kellomäki, S., Peltola, H., Asikainen, A. 2011b. Impacts of thinning and fertilization on timber and energy wood production in Norway spruce and Scots pine: scenario analyses based on ecosystem model simulations. Forestry 84(2), 159-175. 
564 Taylor, K.E., Stouffer, R.J., Meehl, G.A. 2012. An Overview of CMIP5 and the experiment 565 design. Bull. American Meteorological Society 93, 485-498

566 Torssonen, P., Strandman, H., Kellomäki, S., Kilpeläinen A., Jylhä, K., Asikainen, A. and 567 Peltola, H, 2015. Do we need to adapt the choice of main boreal tree species in forest 568 regeneration under the projected climate change? Forestry, in print. doi:10.1093/forestry/cpv023

570

571

572

573

574

575

576

577

578

579

580

581

582

583

584

585

586

587

588

589

Venäläinen, A., Tuomenvirta, H., Pirinen, P., Drebs, A. 2005. A basic Finnish climate data set 1961-2000-description and illustrations. Finnish Meteorological Institute, Reports 2005:5

Zubizarreta-Gerendiain, A., Pukkala, T., Kellomäki, S., Garcia-Gonzalo, J., Ikonen, V.P. and Peltola, H. 2015a. Effects of climate change on optimised stand management in the boreal forests of central Finland. European Journal of Forest Research, 134, 273-280. Doi: $10.1007 / \mathrm{s} 10342-014-0849-8$

Zubizarreta-Gerendiain, A., Pukkala, T., and Peltola, H. 2015b. Effects of wood harvesting and utilisation policies on the carbon balance of forestry under changing climate: a Finnish case study. Forest Policy and Economics, http://dx.doi.org/10.1016/j.forpol.2015.08.007. In print. 


\section{TABLES}

591 Table 1: Generated forest areas with an even age-class distribution (four age classes).

\begin{tabular}{|c|c|c|c|}
\hline $\begin{array}{l}\text { Initial age class } \\
\text { (years) }\end{array}$ & $\begin{array}{c}\text { Age class group } \\
\text { (years) }\end{array}$ & $\begin{array}{c}\text { Area represented } \\
\text { (ha) }\end{array}$ & $\begin{array}{c}\text { Total area } \\
\text { (ha) }\end{array}$ \\
\hline 5 & $0-20$ & 125 & \\
\hline 15 & $0-20$ & 125 & 250 \\
\hline 25 & $21-50$ & 83.3 & \\
\hline 35 & $21-50$ & 83.3 & 250 \\
\hline 45 & $21-50$ & 83.3 & 250 \\
\hline 55 & $51-70$ & 125 & \\
\hline 65 & $51-70$ & 125 & 250 \\
\hline 75 & $>70$ & 125 & 125 \\
\hline 85 & $>70$ & & \\
\hline
\end{tabular}

592

593

594 
595 Table 2: Simulation layout.

\begin{tabular}{lcccc}
\hline & All simulated & \multicolumn{3}{c}{ Selected management } \\
Management & management & alternatives for comparison \\
& alternatives & Heavy & Baseline & Light \\
\hline Rotation length (years) & $60,70,80,90$ & 70 or 90 & 70 or 90 & 70 or 90 \\
Upper thinning threshold change (\%) & $-10,0,10,20$ & -10 & 0 & 20 \\
First thinning, basal area removed (\%) & 50,65 & 65 & 50 & 50 \\
Other thinnings, basal area removed (\%) & $20,30,40$ & 40 & 30 & 20 \\
\hline 596 & & & & \\
\hline
\end{tabular}

596

597 
598

599 Table 3. Change (\%) of total carbon stocks (trees+soil), timber production (i.e. sum of harvested 600 timber volume $\left(\mathrm{m}^{3} \mathrm{ha}^{-1}\right)$ at year 90) and net present value (NPV) for different management 601 scenarios under the climate change (B1 and A2 scenarios) compared to the current climate in 602 different regions (i.e. southern, central and northern Finland).

603

\begin{tabular}{lcccccc} 
& \multicolumn{2}{c}{ South } & \multicolumn{2}{c}{ Central } & \multicolumn{2}{c}{ North } \\
& A2 & \multicolumn{1}{c}{ B1 } & A2 & B1 & A2 & B1 \\
\hline Carbon stocks, \% change & & \\
\hline 70-heavy & -18.5 & -15.4 & -5.5 & -4.9 & 0.1 & 0.3 \\
70-light & -16.8 & -10.7 & -8.0 & -5.8 & 8.0 & 6.9 \\
90-heavy & -18.3 & -11.7 & -6.6 & -4.1 & 7.8 & 7.5 \\
90-base & -14.6 & -12.3 & -8.9 & -6.7 & 4.1 & 3.4 \\
90-light & -15.5 & -12.0 & -10.4 & -4.5 & 6.5 & 5.3 \\
Optimised & -23.2 & -11.0 & -6.7 & -3.6 & 2.7 & 3.9 \\
\hline 70-heavy & -16.2 & -8.5 & -4.3 & -3.6 & 2.2 & 2.3 \\
70-base & -26.4 & -13.2 & -4.2 & -0.9 & 22.3 & 19.4 \\
70-light & -30.5 & -17.0 & -4.7 & -2.4 & 24.2 & 19.9 \\
90-heavy & -38.6 & -18.6 & -2.8 & 0.6 & 25.6 & 21.7 \\
90-base & -43.0 & -13.8 & -4.5 & -2.6 & 26.1 & 23.3 \\
90-light & -30.7 & -19.2 & -2.9 & 2.7 & 21.3 & 20.9 \\
Optimised & -35.6 & -11.0 & -4.9 & 0.9 & 24.0 & 20.8 \\
\hline 70-heavy & -16.1 & -9.0 & -2.2 & -1.2 & 17.0 & 15.4 \\
70- base & -19.6 & -12.0 & -1.0 & -0.5 & 17.2 & 14.1 \\
70-light & -20.6 & -14.6 & -0.1 & 0.1 & 19.6 & 16.6 \\
90-heavy & -22.9 & -9.2 & -1.0 & -0.7 & 17.2 & 16.7 \\
90-base & -20.6 & -10.9 & -2.3 & -0.6 & 20.3 & 15.5 \\
90-light & -19.1 & -11.6 & 1.5 & 2.1 & 13.4 & 15.0 \\
Optimised & -30.1 & -6.8 & -2.5 & 0.0 & 19.1 & 17.5 \\
\hline
\end{tabular}

604

605

606

607

608

609 
610 Table 4. Timber yield $\left(\mathrm{m}^{3} \mathrm{ha}^{-1}\right)$ for 10 years periods and in total over 90 years in the 611 optimised management and its difference (\%) with the 70-base management in different 612 regions (i.e. southern, central and northern Finland) under the current climate (CU) and A2 613 and B1 climate change scenarios.

\begin{tabular}{llllllllllllr}
\hline Years 1-10 & 11-21 & 21-30 & 31-40 & 41-50 & $\mathbf{5 1 - 6 0}$ & $\mathbf{6 1 - 7 0}$ & $\mathbf{7 1 - 8 0}$ & $\mathbf{8 1 - 9 0}$ & $\begin{array}{c}\text { total } \\
\text { timber } \\
\text { yield }\end{array}$ & $\begin{array}{r}\text { \% change } \\
\text { to 70-base }\end{array}$ \\
\hline South & & & & & & & & & & & & \\
CU & 64 & 64 & 64 & 64 & 64 & 64 & 64 & 64 & 73 & 588 & 7 \\
A2 & 43 & 49 & 49 & 49 & 49 & 43 & 43 & 43 & 11 & 378 & -0.6 \\
B1 & 58 & 58 & 58 & 58 & 58 & 58 & 58 & 58 & 58 & 524 & 13 \\
\hline Central & & & & & & & & & & & \\
CU & 62 & 62 & 65 & 65 & 65 & 65 & 65 & 65 & 65 & 579 & 6 \\
A2 & 62 & 62 & 62 & 62 & 62 & 62 & 62 & 62 & 62 & 554 & 6 \\
B1 & 63 & 63 & 63 & 63 & 63 & 63 & 63 & 63 & 72 & 578 & 8 \\
\hline North & & & & & & & & & & & \\
CU & 49 & 49 & 49 & 49 & 49 & 49 & 49 & 49 & 53 & 441 & 7 \\
A2 & 54 & 54 & 54 & 54 & 59 & 63 & 63 & 63 & 72 & 537 & 6 \\
B1 & 51 & 51 & 51 & 58 & 62 & 62 & 62 & 62 & 71 & 529 & 6 \\
\hline
\end{tabular}

614

615 
616 Table 5. Sum of harvested timber and standing volume of growing stock $\left(\mathrm{m}^{3} \mathrm{ha}^{-1}\right)$ at year 90 617 for forests located in southern, central and northern Finland under current climate (CU) and 618 A2 and B1 climate change scenarios. Differences in \% between optimised management plan 619 and single fixed management scenarios within the same climate and region.

\begin{tabular}{|c|c|c|c|c|c|c|}
\hline \multirow[b]{2}{*}{ South } & \multicolumn{2}{|c|}{$\mathbf{C U}$} & \multicolumn{2}{|c|}{ A2 } & \multicolumn{2}{|c|}{ B1 } \\
\hline & $m^{3} h a^{-1}$ & $\%$ & $m^{3} h a^{-1}$ & $\%$ & $m^{3} h a^{-1}$ & $\%$ \\
\hline 70-heavy & 599 & -14.2 & 398 & 1.3 & 500 & -14.8 \\
\hline 70 - base & 630 & -9.7 & 389 & -1.0 & 516 & -12.1 \\
\hline 70-light & 630 & -9.7 & 381 & -3.1 & 502 & -14.5 \\
\hline 90-heavy & 638 & -8.6 & 331 & -15.8 & 530 & -9.7 \\
\hline 90-base & 666 & -4.6 & 359 & -8.7 & 541 & -7.8 \\
\hline 90-light & 659 & -5.6 & 316 & -19.6 & 517 & -11.9 \\
\hline Optimised & 698 & & 393 & & 587 & \\
\hline \multicolumn{7}{|l|}{ Central } \\
\hline 70-heavy & 592 & -14.5 & 565 & -14.0 & 586 & -15.4 \\
\hline 70- base & 625 & -9.7 & 587 & -10.7 & 618 & -10.8 \\
\hline 70-light & 615 & -11.1 & 584 & -11.1 & 614 & -11.4 \\
\hline 90-heavy & 638 & -7.8 & 592 & -9.9 & 624 & -10.0 \\
\hline 90-base & 647 & -6.5 & 615 & -6.4 & 659 & -4.9 \\
\hline 90-light & 661 & -4.5 & 603 & -8.2 & 657 & -5.2 \\
\hline Optimised & 692 & & 657 & & 693 & \\
\hline \multicolumn{7}{|l|}{ North } \\
\hline 70-heavy & 463 & -14.6 & 574 & -15.6 & 551 & -14.7 \\
\hline 70- base & 475 & -12.4 & 599 & -11.9 & 577 & -10.7 \\
\hline 70-light & 467 & -13.8 & 601 & -11.6 & 577 & -10.7 \\
\hline 90-heavy & 493 & -9.0 & 601 & -11.6 & 577 & -10.7 \\
\hline 90-base & 519 & -4.2 & 642 & -5.6 & 620 & -4.0 \\
\hline 90-light & 514 & -5.2 & 650 & -4.4 & 619 & -4.2 \\
\hline Optimised & 542 & & 680 & & 646 & \\
\hline
\end{tabular}

620

621

622 


\section{FIGURE CAPTIONS}

625 Fig1. Average carbon stock (soil, trees and total carbon) of forests ( $\mathrm{Mg} \mathrm{ha}^{-1}$ year-1) over 90 626 years simulation period under the current climate and climate change scenarios A2 and B1 in 627 southern, central and northern Finland. In addition to optimised management, six-fixed 628 management scenarios were applied with rotation length of 70 or 90 years, and heavy, 629 baseline or light thinnings (see Table 2).

630

631 Fig2. Timber yield (harvested $\log$ and pulp wood, $\mathrm{m}^{3}$ ha ${ }^{-1}$ ) under the current climate and 632 climate change scenarios A2 and B1 in southern, central and northern Finland. In addition to 633 the optimised management, six fixed management scenarios were applied with rotation length 634 of 70 or 90 years, and heavy, baseline or light thinnings (see Table 2).

635

636 Fig3. Net present value (NPV, euros ha ${ }^{-1}$ ) over 90 years simulation period under the current 637 climate and climate change scenarios A2 and B1 in southern, central and northern Finland. In 638 addition to optimised management, six-fixed management scenarios were applied with 639 rotation length of 70 or 90 years, and heavy, baseline or light thinnings (see Table 2). 
$641 \quad$ FIG1 (excel)

642

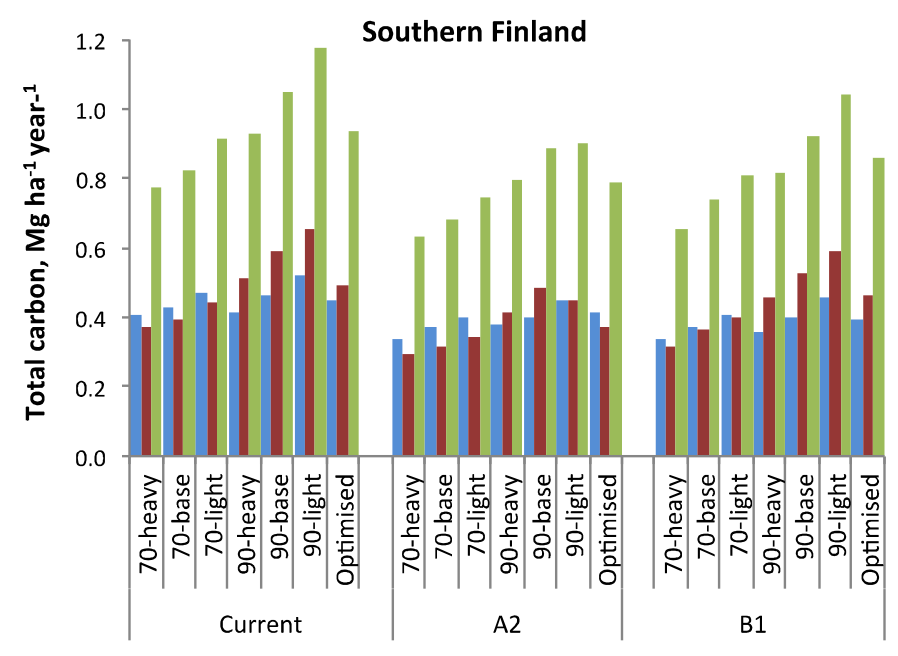

1.2

Central Finland

1

- Soil

- Trees

- Total

6

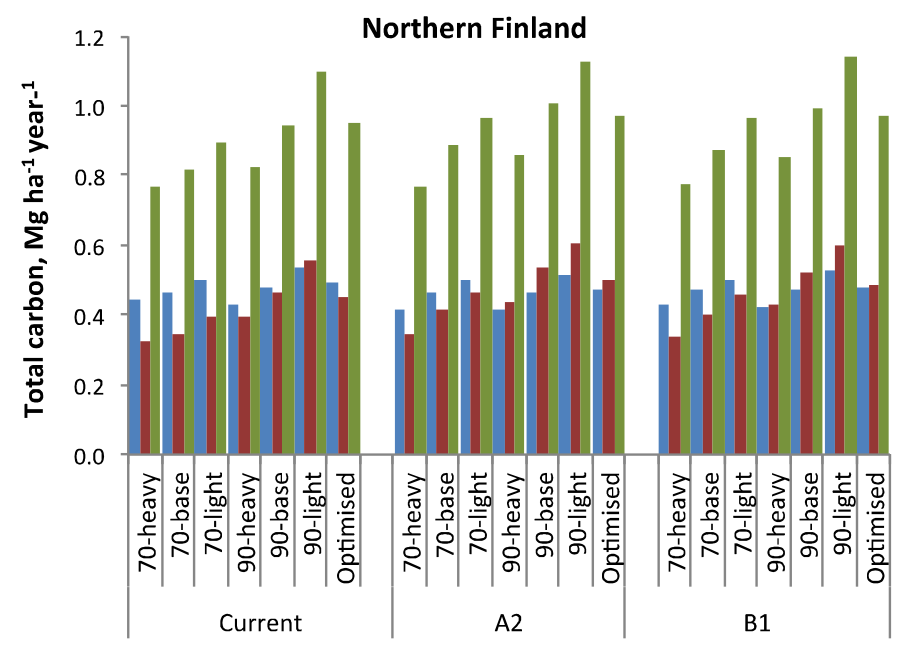

644 
646

647
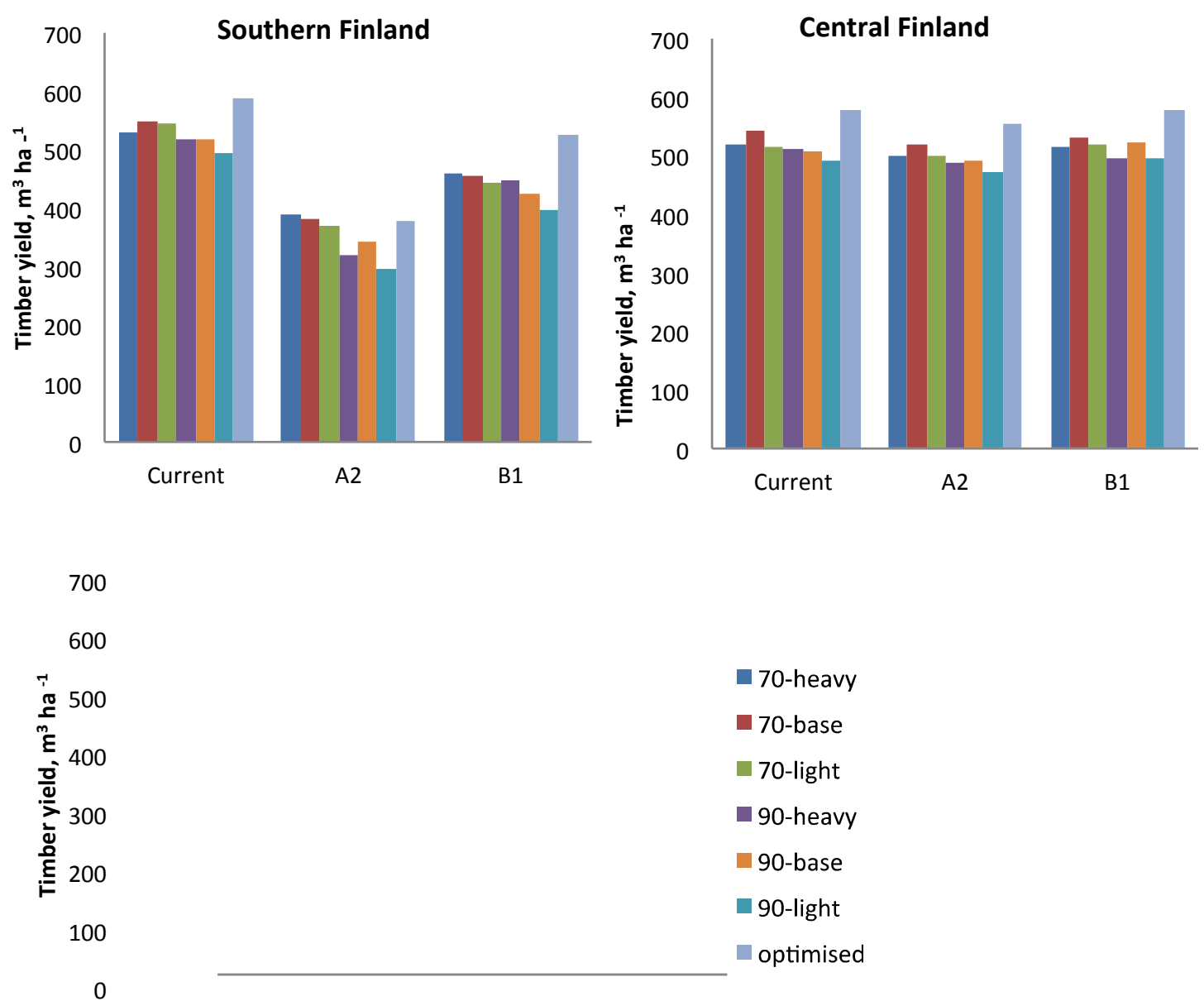

648

649

650 
$651 \quad$ FIG3 (excel)

652
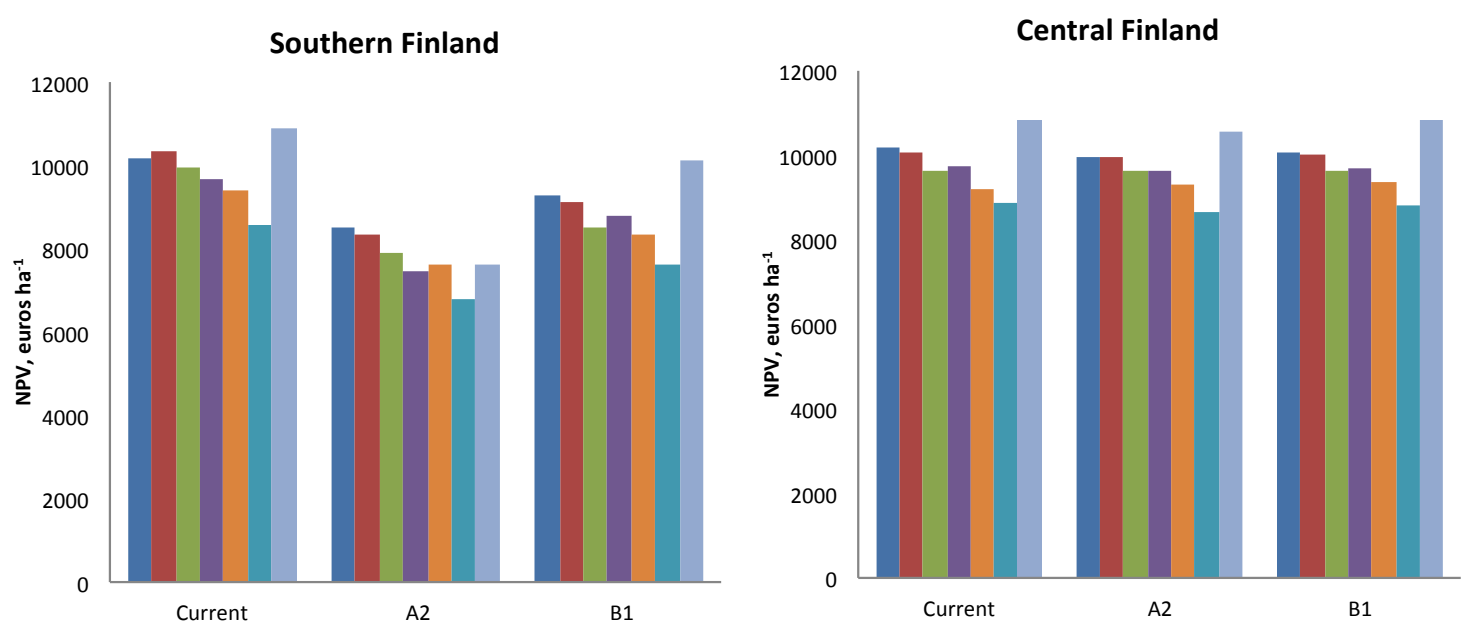

653

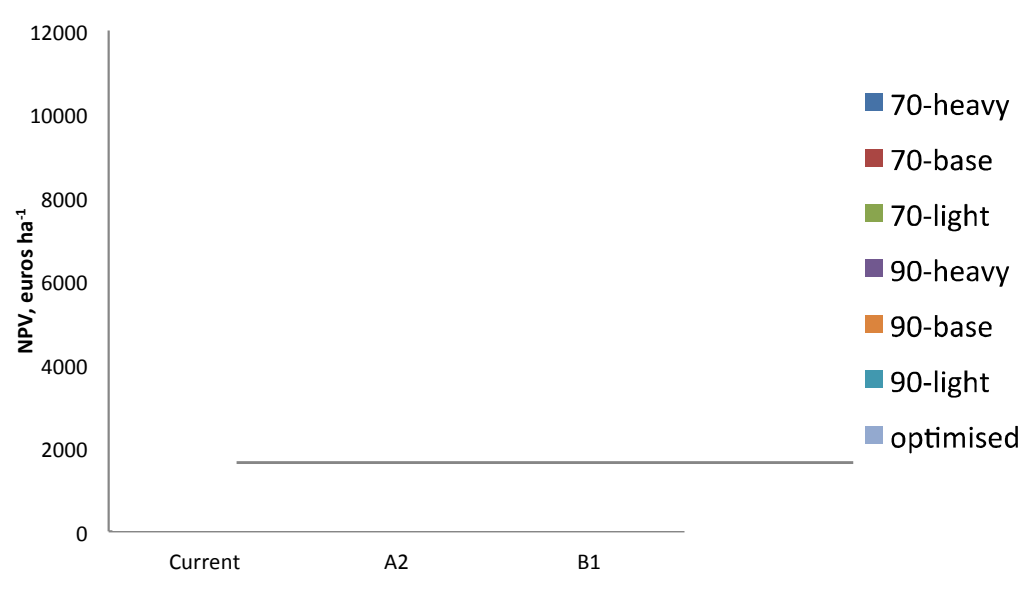

654

655

656

https://mc06.manuscriptcentral.com/cjfr-pubs 